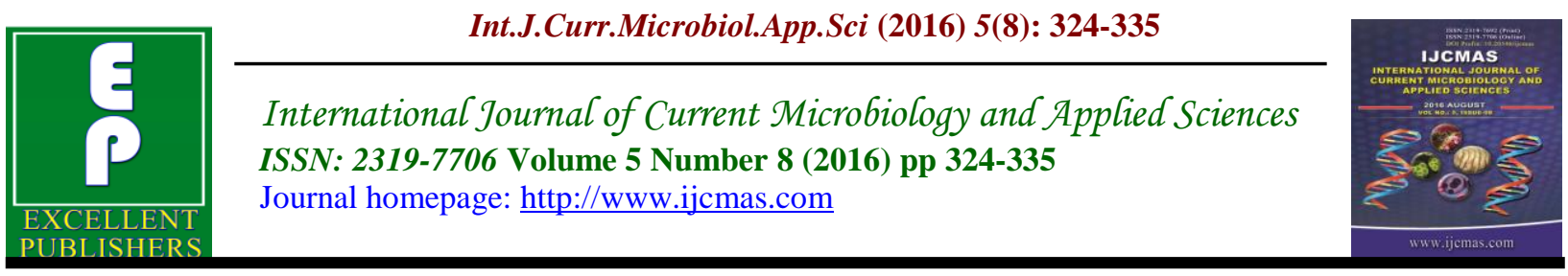

Original Research Article

http://dx.doi.org/10.20546/ijcmas.2016.508.035

\title{
Antifouling Activity of Extracts from Mangroves against Biofouling Bacteria Isolated from Boats in Royapuram, Chennai, India
}

\author{
S. Nandhini ${ }^{1}$ and K. Revathi ${ }^{2}$ \\ ${ }^{1}$ Department of Microbiology, Ethiraj College for Women, Chennai, Tamil Nadu, India \\ ${ }^{2}$ Department of Advanced Zoology and Biotechnology, Ethiraj College for Women, Chennai, \\ Tamil Nadu, India \\ *Corresponding author
}

\begin{abstract}
A B S T R A C T
Keywords

Biofilm;

biofouling;

antifouling;

mangroves,

16SrRNA

Article Info

Accepted:

17 July 2016

Available Online:

10 August 2016

Biofouling is a process of attachment and growth of micro- and macro-foulers on submerged natural or manmade marine structures causing huge economic and environmental losses worldwide. Marine organisms are rich source of structurally novel and biologically active metabolites and can be one of the best replacement options as natural antifoulants against toxic heavy-metal-based paints. Mangroves possess a diverse array of bioactive compounds; hence, an attempt was done to evaluate its antifouling (AF) potential. In this study, a biofoulant sample was collected from boats, and culturable marine bacteria were isolated on Zobell's marine agar medium. The 16SrRNA sequencing of five isolates was done and confirmed to be Vibrio parahemolyticus, Vibrio nereis, Micrococcus luteus, Exiguobacterium profundum and Salinicocoocu shispanicus. In vitro screening for AF potential of methanolic extract of two mangroves(leaves, bark and root), viz. Bruguiera cylindrica and Rhizophora apiculata collected from Pichavaram against biofouling bacteria was done by the agar diffusion method. The results indicated that mangroves have potent $\mathrm{AF}$ components and can be used as a natural source of antifoulant.
\end{abstract}

\section{Introduction}

Biofouling involves colonization of structures that are either living or artificial mainly in the aquatic environment by micro(bacteria, diatoms, spores of macroalgae and protozoans) and macro-foulers (barnacles, bryozoans, algae and tubeworms). Biofilm formation by bacteria is the key step during marine fouling which serves as a focus for the attachment and growth of invertebrates, sessile plants and animals (Camps et al., 2011).
Mature biofouling communities are complex, highly dynamic ecosystems, which once established are extremely difficult to eradicate creating extensive problems in marine technology such as roughness on the ships' hulls, reducing efficiency, speed and maneuverability (Manilal et al., 2010). The problem is so severe worldwide that the expenditure incurred on antifouling (AF) measures alone is approximately US $\$ 6.5$ billion a year (Bhadury et al., 2004). 
AF includes both defensive biological processes used by marine organisms to limit epibiosis and methods used to protect submerged structures such as ships' hulls (Yebra et al., 2004), aquaculture equipment (Braithwaite and McEvoy 2004) and optical devices (Patil et al., 2007). One of the most promising alternatives to tributyltin or heavy-metal-based paints is the development of naturally occurring AF compounds from marine organisms. To date, a variety of Natural Product Antifoulants (NPAs) have been isolated from different marine organisms, including marine bacteria, algae, sponges, corals, seaweeds, seagrasses and mangrove plants (Deepa et al., 2014; Qian et al., 2010; Raveendran et al., 2009). A wide variety of laboratory AF assays have been developed using different test organisms including bacteria, diatoms, algae, barnacle, mussels and other species, which are major contributors to fouling (Briand 2009).

Mangroves are widespread in tropical and subtropical regions, growing in the saline interdial zones of sheltered coastlines and contain biologically active antimicrobial compounds (Abeysinghe et al., 2006; Ravikumar et al., 2011). Several species of mangroves have been reported to contain secondary metabolites like alkaloids, phenolics, steroids and terpenoids, which are of toxicological, pharmacological and ecological importance (Bandaranayake 2002).But, there is scant information on the isolation of antifouling compounds from mangrove species. Therefore, an attempt was made to evaluate the AF potential of two mangrove species, viz. Bruguiera cylindrica and Rhizophora apiculata against the biofouling bacteria.

\section{Materials and Methods}

\section{Collection of mangroves}

Two species of mangroves, viz. Bruguiera cylindrica and Rhizophora apiculata, were collected and identified from Pichavaram

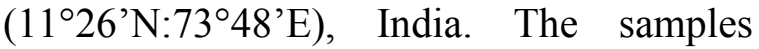
were washed with distilled water to remove salt, dirt and other associated debris. Clean samples were then dried under shade for one week at room temperature. The leaves, bark and root of the mangroves were separated and ground.

\section{Extraction of crude bioactives}

The leaves, bark and root of the mangroves were extracted in methanol at 1:3 ratio for $72 \mathrm{~h}$ and evaporated to dryness using a rotary evaporator at $40^{\circ} \mathrm{C}$. The residues were preserved at $4^{\circ} \mathrm{C}$ for further analysis.

\section{Isolation of biofouling bacteria}

Biofouling samples were collected from boats in Royapuram $\left(13^{\circ} 7^{\prime} 31.98^{\prime \prime} \mathrm{N}, 80^{\circ} 17^{\prime} 51.52^{\prime \prime} \mathrm{E}\right)$, Chennai, India. The biofilms were scraped off from five different locations and placed in a sterile container; an additional $100 \mathrm{ml}$ of sterilized seawater was added and placed in an icebox. The sample was subjected to vigorous vortexing for $5 \mathrm{~min}$ and serially diluted using sterilized seawater. A volume of $100 \mu \mathrm{l}$ of the diluents was spread on sterile Zobell's Marine Agar 2216 (Himedia, Mumbai). The plates were incubated at room temperature $\left(27^{\circ} \mathrm{C}-30^{\circ} \mathrm{C}\right)$ for 5 days, and isolated colonies showing different morphological characteristics were identified using minimum biochemical tests (Das et al., 2007) and confirmed by 16SrRNA sequencing. The purified isolates were then cultured on Zobell's Marine Slant and stored at $4^{\circ} \mathrm{C}$.

\section{S rRNA sequencing}

Genomic DNA was isolated using an InstaGene $^{\mathrm{TM}}$ Matrix Genomic DNA isolation kit and amplified by using PCR primers 27F (5'AGAGTTTGATC MTG 
GCTCAG-3') and 1492 (5'TACGGYT ACC TTGTTACGACTT-3'). The sequencing was done using 518F (5'-CCAGCAGCCGC GGTAATACG-3') and 800R (5'-TACCAG GGTATCTAATCC-3') primers. Sequence reactions were performed using $\mathrm{ABF}$ prism BIG DyeTM Termination cycle sequencing kits with AmpliTaq ${ }^{\mathrm{R}}$ DNA polymerase (FS enzyme) Applied Biosystem. The 16S rRNA sequence was blast using NCBI Blast similarity search tool.

\section{AF bioassay}

The antimicrofouling activity of different concentrations $(100 \mu \mathrm{g} / \mathrm{ml}$ and $200 \mu \mathrm{g} / \mathrm{ml})$ of leaf extracts against five test organisms was done by the agar diffusion method (Nathan et al., 1978). A volume of $100 \mu \mathrm{g} / \mathrm{ml}$ of methanolic extract of bark and root of mangroves was also assayed similarly. All the assays were done in triplicate. After incubation, the plates were observed for the zone of inhibition around the wells, and the zone size was measured in millimetres.

Antimicrobial efficacy was graded based on the zone diameter as high activity (> 15 $\mathrm{mm})$, moderately active $(10-14 \mathrm{~mm})$, trace activity (5-9 $\mathrm{mm})$ and no activity (<4 mm) (Rios et al., 1988).

\section{Minimum inhibitory concentration assay}

Determination of MIC value for methanolic extract that showed high antibacterial activity was determined by broth dilution method (Ravi et al., 2011). Various dilutions of $(3.25,6,12,24.5,50,100,500$, and 1000 $\mu \mathrm{g} / \mathrm{ml})$ of leaf extracts was prepared with DMSO and mixed with $50 \mu \mathrm{l}$ of $24 \mathrm{~h}$ old bacterial inoculum.

After incubation, turbidity were measured and the lowest concentration of the extract inhibiting the growth of test bacteria was observed and tabulated.
The identification of functional groups in crude mangrove parts was also determined through FTIR (Shimadzu).

\section{Results and Discussion}

Marine bacteria from boats in the form of biofilms or microfouling were isolated and cultured, and five morphologically distinct isolates were identified as Vibrio parahemolyticus BF-1, Vibrio nereis BF-2, Salinicoccus hispanicus BF-3, Micrococcus luteus BF-4 and Exiguobacterum profundum $B F-5$ using $16 \mathrm{~S}$ rRNA sequencing. The efficacy of the crude methanolic extracts of Bruguiera cylindrica and Rhizophora apiculata was evaluated against these five biofouling bacteria (Tables 2 and 3). The effectiveness of the active compounds present in the plant extract showed growth inhibition as clear areas surrounding the well.

Methanolic leaf extract of Rhizophora apiculata at $100 \mu \mathrm{g} / \mathrm{ml}$ concentration exhibited a wide spectrum of activity, with maximum zone of inhibition against Vibrio parahemolyticus BF-1 (16 $\mathrm{mm})$ and minimum against Vibrio nereis BF-2 (Figure 1).Bruguiera cylindrica showed maximum activity against Exiguobacterum profundum $\mathrm{BF}-5(17 \mathrm{~mm})$ and minimum against Vibrio nereis BF-2 (12mm) as shown in Figure 2. At $200 \mu \mathrm{g} / \mathrm{ml}$ concentration the maximum zone of inhibition for Rhizophora apiculata was $24 \mathrm{~mm}$ against Vibrio parahemolyticus BF-1 and Exiguobacterum profundum BF-5 and $25 \mathrm{~mm}$ for Bruguiera cylindrica against Micrococcus luteus BF-4. Antimicrobial activity of both the mangroves was less against Vibrio nereis BF-2 and Salinicoccus hispanicus BF-3.

Crude leaf extracts of Bruguiera cylindrica and Rhizophora apiculata showed higher AF activity than bark and root extract 
irrespective of concentration. The bark of Bruguiera cylindrica showed better AF activity against all bacteria compared to Rhizophora apiculata with maximum against Vibrio parahemolyticus $\mathrm{BF}-1$ and Micrococcus luteus BF-4 as shown in Figure 3. The root extract of both the mangroves showed almost similar inhibition results against the biofouling bacteria (Figure 4). The difference in the antimicrobial effect of mangroves could be due to the quantity of antimicrobial components present in each form. The observation can be rationalized in terms of the polarity of the compounds being extracted by the solvent, intrinsic bioactivity and ability to diffuse in the media used for the assay (Nair et al., 2007).

The extract of Rhizophora apiculata showed MIC value of $50 \mu \mathrm{g} / \mathrm{ml}$ against Vibrio parahemolyticus BF-1, Exiguobacterium profundum BF-5 and $100 \mu \mathrm{g} / \mathrm{ml}$ against Vibrio nereis BF-2, Salinicoccus hispanicus BF-3 and Micrococcus luteus BF-4.
Likewise, Bruguiera cylindrica exhibited MIC value of $50 \mu \mathrm{g} / \mathrm{ml}$ against Micrococcus luteus BF-4 and Exiguobacterium profundum BF-5 followed by MIC value of $100 \mu \mathrm{g} / \mathrm{ml}$ against the remaining bacteria (Table 4). Overall, the mangrove extracts of Bruguiera cylindrica and Rhizophora apiculata showed better antibacterial activity against the strains Vibrio parahemolyticus BF-1, Exiguobacterium profundum BF-5 and Salinicoccus hispanicus BF-3.

Fourier Transform Infrared Spectroscopy (FTIR) analysis revealed the presence of bonds such as $\mathrm{O}-\mathrm{H}$ stretch, H-bond (alcohols, phenols), C-H stretch (alkanes), $\mathrm{C}-\mathrm{O}$ stretch (alcohols, carboxylic acids, esters and ethers), $\mathrm{C}-\mathrm{Br}$ (alkyl halides) in all the extracts as shown in Table 4 (Figures 510). The inhibitory activity is mainly correlated with these active functional groups.

Table.1 Details of BLAST analysis, percentage of similarity and NCBI accession numbers of biofouling bacteria isolated from boats

\begin{tabular}{|l|l|l|l|l|l|}
\hline S. No. & $\begin{array}{l}\text { Assigned } \\
\text { code }\end{array}$ & $\begin{array}{l}\text { Sequence } \\
\text { length }\end{array}$ & $\begin{array}{l}\text { Similarity } \\
\boldsymbol{\%}\end{array}$ & BLAST results & $\begin{array}{l}\text { NCBI's accession } \\
\text { number }\end{array}$ \\
\hline 1. & BF-1 & 1486 & 99 & Vibrio parahemolyticus & KR137715 \\
\hline 2. & BF-2 & 1473 & 99 & Vibrio nereis & KR137716 \\
\hline 3. & BF-3 & 1507 & 99 & Salinicoccushispanicus & KR137717 \\
\hline 4. & BF-4 & 1467 & 99 & Micrococcus luteus & KR137718 \\
\hline 5. & BF-5 & 1496 & 99 & $\begin{array}{l}\text { Exiguobacterium } \\
\text { profundum }\end{array}$ & KR137719 \\
\hline
\end{tabular}

Table.2 Antibacterial activity of leaf extract (zone of inhibition in $\mathrm{mm}$ ).

\begin{tabular}{|c|c|c|c|c|c|}
\hline \multirow{2}{*}{$\begin{array}{c}\text { S. } \\
\text { No }\end{array}$} & \multirow[b]{2}{*}{ Name of the organism } & \multicolumn{2}{|c|}{ Rhizophora apiculata } & \multicolumn{2}{|c|}{ Bruguiera cylindrica } \\
\hline & & $100 \mu \mathrm{g} / \mathrm{ml}$ & $200 \mu \mathrm{g} / \mathrm{ml}$ & $100 \mu \mathrm{g} / \mathrm{ml}$ & $200 \mu \mathrm{g} / \mathrm{ml}$ \\
\hline 1 & Vibrio parahemolyticusBF-1 & 16 & 24 & 13 & 23 \\
\hline 2 & Vibrio nereisBF-2 & 12 & 20 & 12 & 21 \\
\hline 3 & Salinicoccus hispanicus BF-3 & 15 & 20 & 13 & 22 \\
\hline 4 & Micrococcus luteusBF-4 & 14 & 21 & 14 & 25 \\
\hline 5 & Exiguobacterium profundumBF-5 & 15 & 24 & 17 & 24 \\
\hline
\end{tabular}


Table.3 Antibacterial activity of bark and root extracts (zone of inhibition in $\mathrm{mm}$ ).

\begin{tabular}{|c|l|c|c|c|c|}
\hline \multirow{2}{*}{$\begin{array}{c}\text { S. } \\
\text { No }\end{array}$} & \multicolumn{1}{|c|}{ Name of the organism } & \multicolumn{2}{c|}{ Rhizophora apiculata } & \multicolumn{2}{c|}{ Bruguiera cylindrical } \\
\cline { 3 - 6 } & Bark & Root & Bark & Root \\
\hline 1 & Vibrio parahemolyticusBF-1 & 12 & 12 & 12 & 12 \\
\hline 2 & Vibrio nereisBF-2 & 11 & 10 & 11 & 10 \\
\hline 3 & SalinicoccushispanicusBF-3 & 12 & 11 & 12 & 11 \\
\hline 4 & Micrococcus luteusBF-4 & 11 & 11 & 11 & 11 \\
\hline 5 & Exiguobacteriumprofundum BF-5 & 12 & 10 & 12 & 10 \\
\hline
\end{tabular}

Table.4 MIC of methanolic leaf extracts

\begin{tabular}{|c|l|c|c|}
\hline S.No & \multicolumn{1}{|c|}{ Name of the organism } & $\begin{array}{c}\text { Rhizophora apiculata } \\
\mu \mathrm{g} / \mathrm{ml}\end{array}$ & $\begin{array}{c}\text { Bruguiera cylindrica } \\
\mu \mathrm{g} / \mathrm{ml}\end{array}$ \\
\hline 1. & Vibrio parahemolyticusBF-1 & 50 & 100 \\
\hline 2. & Vibrio nereisBF-2 & 100 & 100 \\
\hline 3. & Salinicoccus hispanicus BF-3 & 100 & 100 \\
\hline 4. & Micrococcus luteusBF-4 & 100 & 50 \\
\hline 5. & Exiguobacterium profundum BF-5 & 50 & 50 \\
\hline
\end{tabular}

Fig.1 Antibacterial activity of leaf extract of Rhizophora apiculata

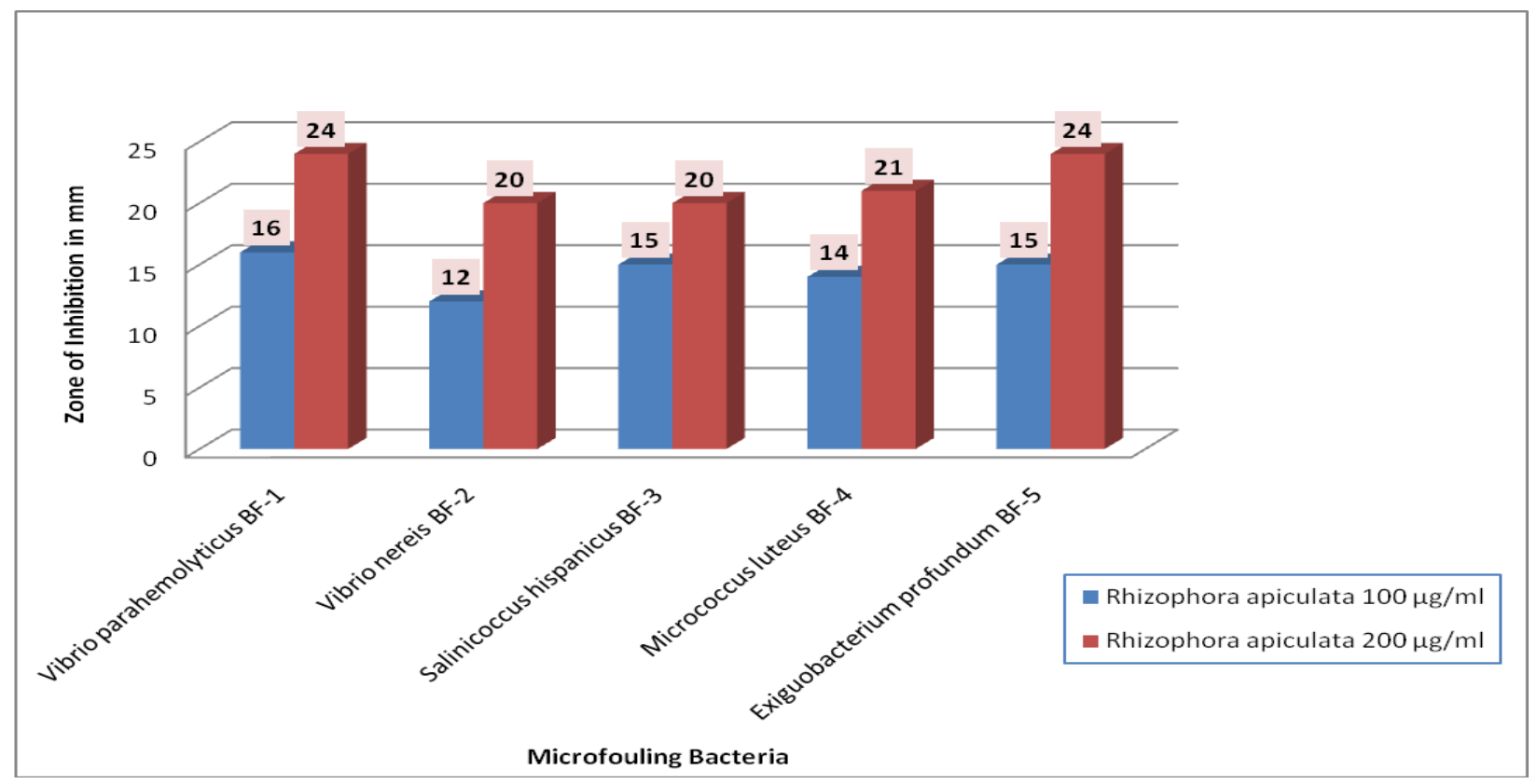


Table.5 Identification of functional groups through FTIR analysis

\begin{tabular}{|c|c|c|c|}
\hline Name of the species & Frequency $\left(\mathrm{cm}^{-1}\right)$ & Bond & Functional group \\
\hline \multicolumn{4}{|c|}{ Rhizophora apiculata } \\
\hline \multirow[t]{7}{*}{ Leaves } & $3408(b, m)$ & $\begin{array}{l}\mathrm{O}-\mathrm{H} \text { stretch, } \mathrm{H}- \\
\text { bonded }\end{array}$ & Alcohols, phenols \\
\hline & $2954(\mathrm{~s})$ & $\mathrm{C}-\mathrm{H}$ stretch & Alkanes \\
\hline & $1734(\mathrm{~s})$ & $\mathrm{C}=\mathrm{O}$ stretch & Aliphatic esters, aldehydes \\
\hline & $1647(\mathrm{~m})$ & $\mathrm{N}-\mathrm{H}$ bend & $1^{\circ}$ amines \\
\hline & $1058(\mathrm{~s})$ & $\mathrm{C}-\mathrm{O}$ stretch & $\begin{array}{l}\text { Alcohols, carboxylic } \\
\text { acids, esters and ethers }\end{array}$ \\
\hline & $876(s)$ & C-H “opp" & Aromatics \\
\hline & $653(\mathrm{~s})$ & C-Br stretch & Alkyl halides \\
\hline \multirow[t]{6}{*}{ Bark } & $3422(s, b)$ & $\begin{array}{l}\mathrm{O}-\mathrm{H} \text { stretch, H- } \\
\text { bonded }\end{array}$ & Alcohols, phenols \\
\hline & $2925(\mathrm{~m})$ & C-H stretch & Alkanes \\
\hline & $1739(\mathrm{~s})$ & $\mathrm{C}=\mathrm{O}$ stretch & Aliphatic esters, aldehydes \\
\hline & $1628(\mathrm{~m})$ & $\mathrm{N}-\mathrm{H}$ bend & $1^{\circ}$ amines \\
\hline & $1043(\mathrm{~m})$ & $\mathrm{C}-\mathrm{O}$ stretch & $\begin{array}{l}\text { Alcohols, carboxylic } \\
\text { acids, esters and ethers }\end{array}$ \\
\hline & $775(\mathrm{~m})$ & $\mathrm{C}-\mathrm{Cl}$ stretch & Alkyl halides \\
\hline \multirow[t]{5}{*}{ Root } & 3395 (b) & $\begin{array}{l}\mathrm{O}-\mathrm{H} \text { stretch, } \mathrm{H}- \\
\text { bonded }\end{array}$ & Alcohols, phenols \\
\hline & $2925(\mathrm{~s})$ & $\mathrm{C}-\mathrm{H}$ stretch & Alkanes \\
\hline & $1736(\mathrm{~m})$ & $\mathrm{C}=\mathrm{O}$ stretch & Aliphatic esters, aldehydes \\
\hline & $1634(\mathrm{~s})$ & $\mathrm{N}-\mathrm{H}$ bend & $1^{\circ}$ amines \\
\hline & $1044(\mathrm{~s})$ & C-O stretch & $\begin{array}{l}\text { Alcohols, carboxylic } \\
\text { acids, esters and ethers }\end{array}$ \\
\hline \multicolumn{4}{|l|}{ Bruguiera cylindrical } \\
\hline \multirow[t]{7}{*}{ Leaves } & 3416 (b) & $\begin{array}{l}\text { O-H stretch, H- } \\
\text { bonded }\end{array}$ & Alcohols, Phenols \\
\hline & $2925(\mathrm{~m})$ & C-H stretch & Alkanes \\
\hline & $1736(\mathrm{~s})$ & $\mathrm{C}=\mathrm{O}$ stretch & Aliphatic esters, aldehydes \\
\hline & $1623(\mathrm{~m})$ & $\mathrm{N}-\mathrm{H}$ bend & $1^{\circ}$ amines \\
\hline & $1324(\mathrm{~m})$ & C-N stretch & Aromatic amines \\
\hline & $1038(\mathrm{~m})$ & C-O stretch & $\begin{array}{l}\text { Alcohols, carboxylic } \\
\text { acids, esters and ethers }\end{array}$ \\
\hline & $660(\mathrm{~m}):$ & $\mathrm{C}=\mathrm{C}-\mathrm{H}: \mathrm{C}-\mathrm{H}$ bend & Alkynes \\
\hline \multirow[t]{5}{*}{ Bark } & $3422(\mathrm{~s}, \mathrm{~b})$ & $\begin{array}{l}\mathrm{O}-\mathrm{H} \text { stretch, H- } \\
\text { bonded }\end{array}$ & Alcohols, Phenols \\
\hline & $2925(\mathrm{~m}, \mathrm{n})$ & C-H stretch & Alkanes \\
\hline & $1739(\mathrm{~s}, \mathrm{n})$ & $\mathrm{C}=\mathrm{O}$ stretch & Aliphatic esters, aldehydes \\
\hline & $1628(\mathrm{~m}, \mathrm{sh})$ & $\mathrm{N}-\mathrm{H}$ bend & $1^{\circ}$ amines \\
\hline & $1043(\mathrm{~m}, \mathrm{~b})$ & C-O stretch & $\begin{array}{l}\text { Alcohols, carboxylic } \\
\text { acids, esters and ethers }\end{array}$ \\
\hline
\end{tabular}




\begin{tabular}{|l|l|l|l|}
\hline \multirow{3}{*}{ Root } & $775(\mathrm{~s}, \mathrm{n})$ & C-Cl stretch & Alkyl halides \\
\hline & $3418(\mathrm{~m}, \mathrm{~b})$ & $\begin{array}{l}\text { O-H stretch, H- } \\
\text { bonded }\end{array}$ & Alcohols, Phenols \\
\cline { 2 - 4 } & $2926(\mathrm{~m}, \mathrm{n})$ & C-H stretch & Alkanes \\
\hline $1738(\mathrm{~s}, \mathrm{n})$ & C=O stretch & Aliphatic esters, aldehydes \\
\hline $1623(\mathrm{~s}, \mathrm{n})$ & N-H bend & $1^{\circ}$ amines \\
\cline { 2 - 4 } & $1036(\mathrm{~s}, \mathrm{~b})$ & C-O stretch & $\begin{array}{l}\text { Alcohols, carboxylic } \\
\text { acids, esters and ethers }\end{array}$ \\
\hline
\end{tabular}

Fig.2 Antibacterial activity of leaf extract of Bruguiera cylindrica

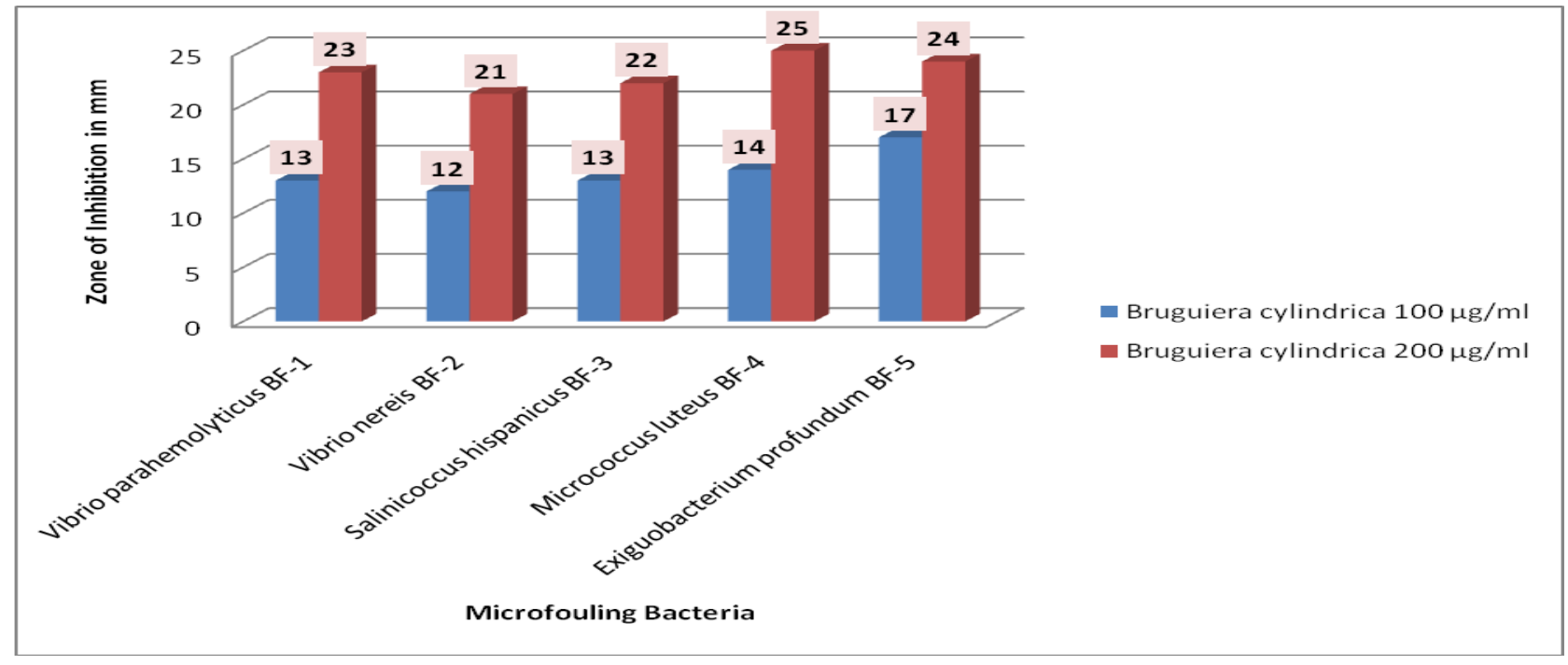

Fig.3 Antibacterial activity of bark extract

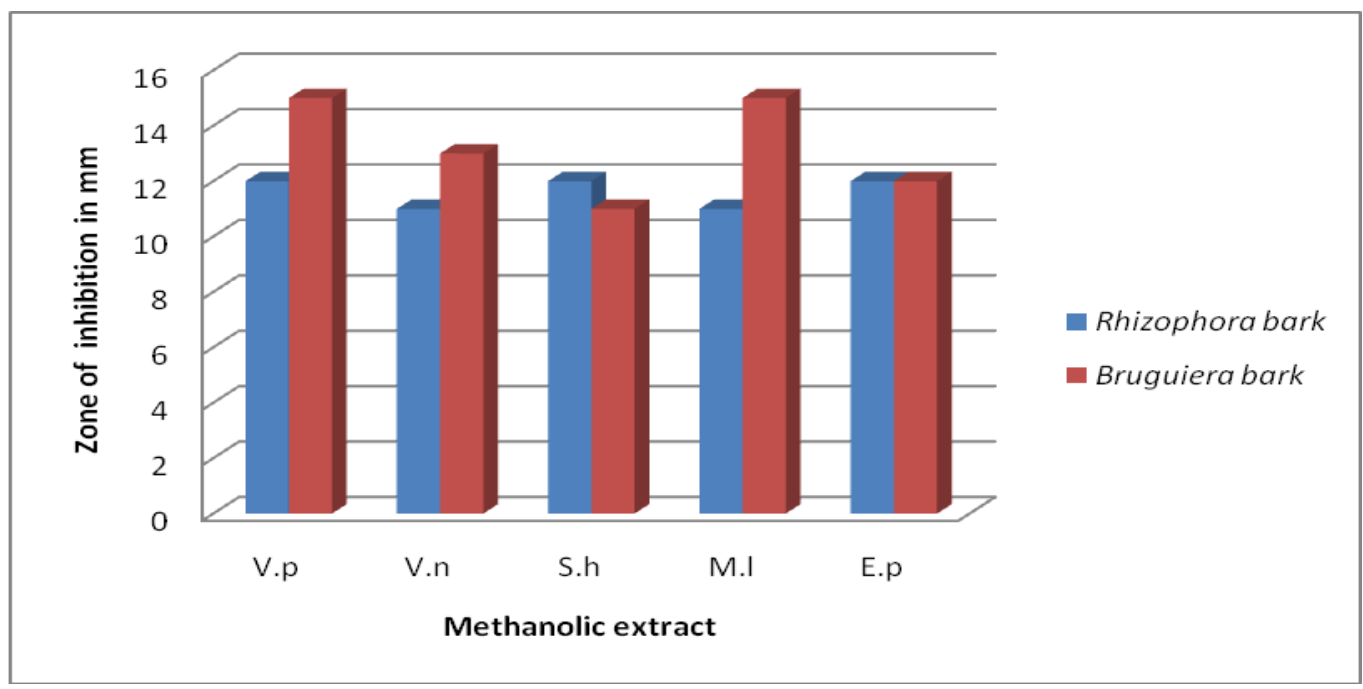


Fig.4 Antibacterial activity of root extract

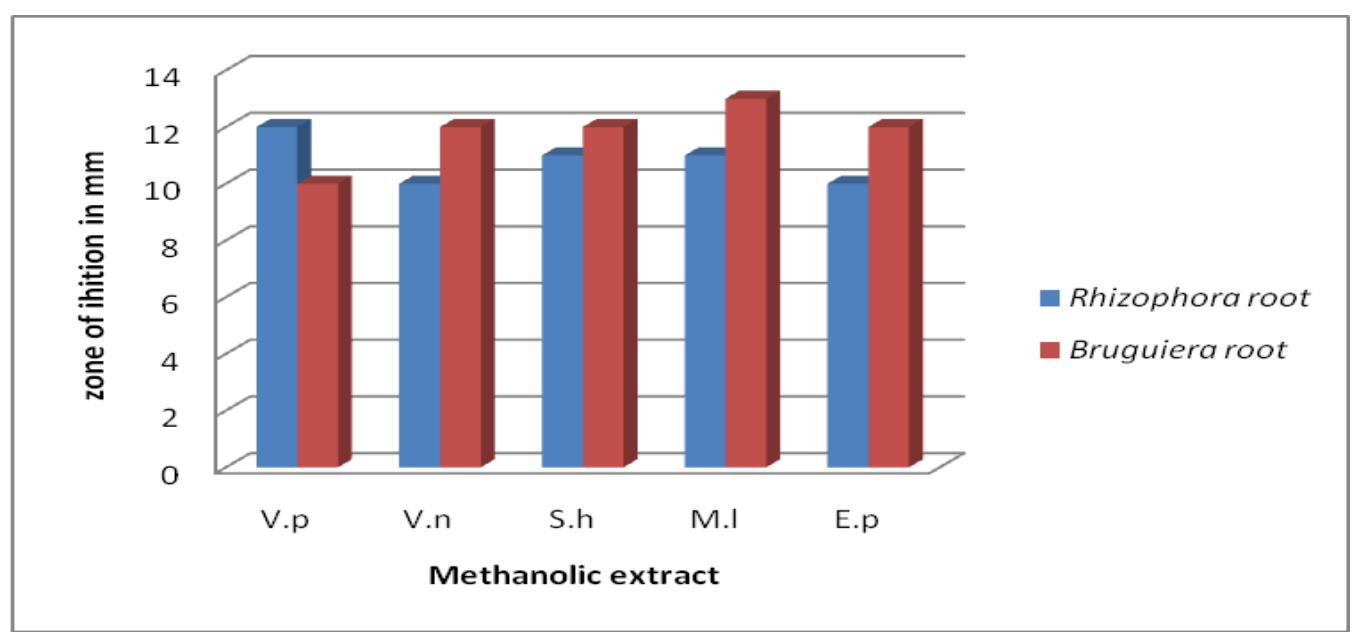

Fig.5 FTIR spectrum of B. cylindricl leaves

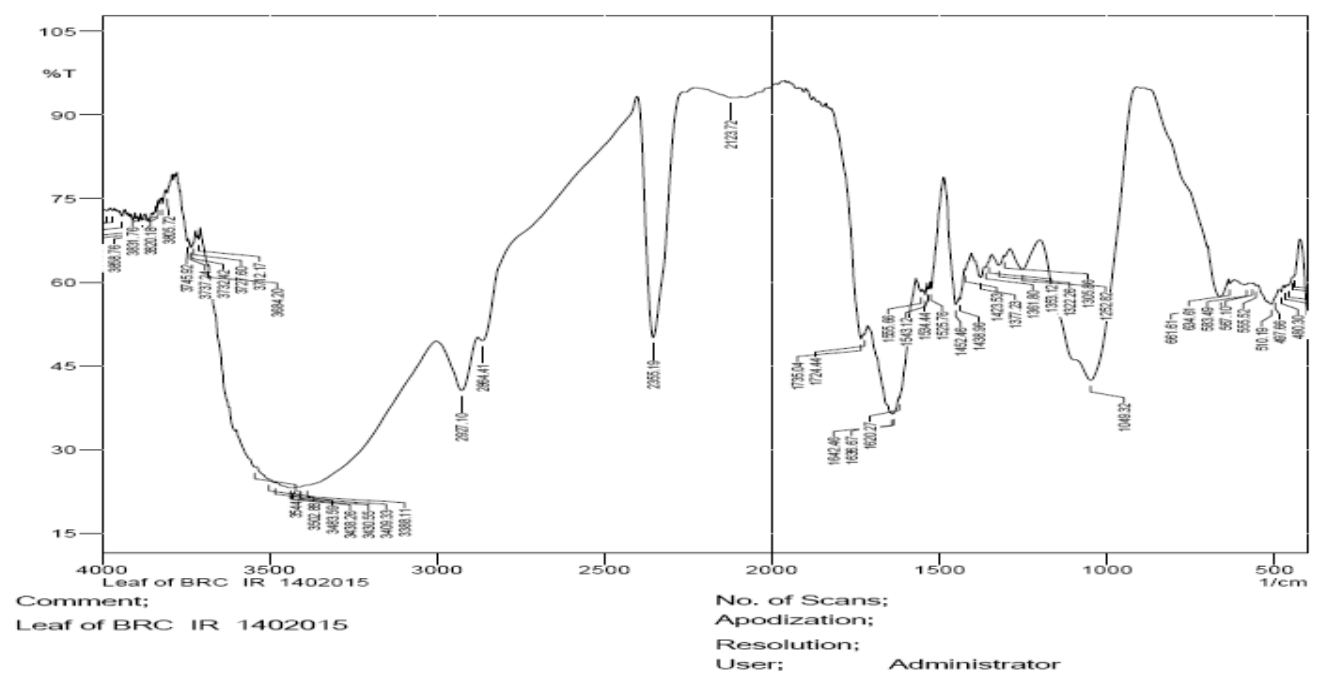

Fig.6 FTIR spectrum of $R$. apiculata leaves

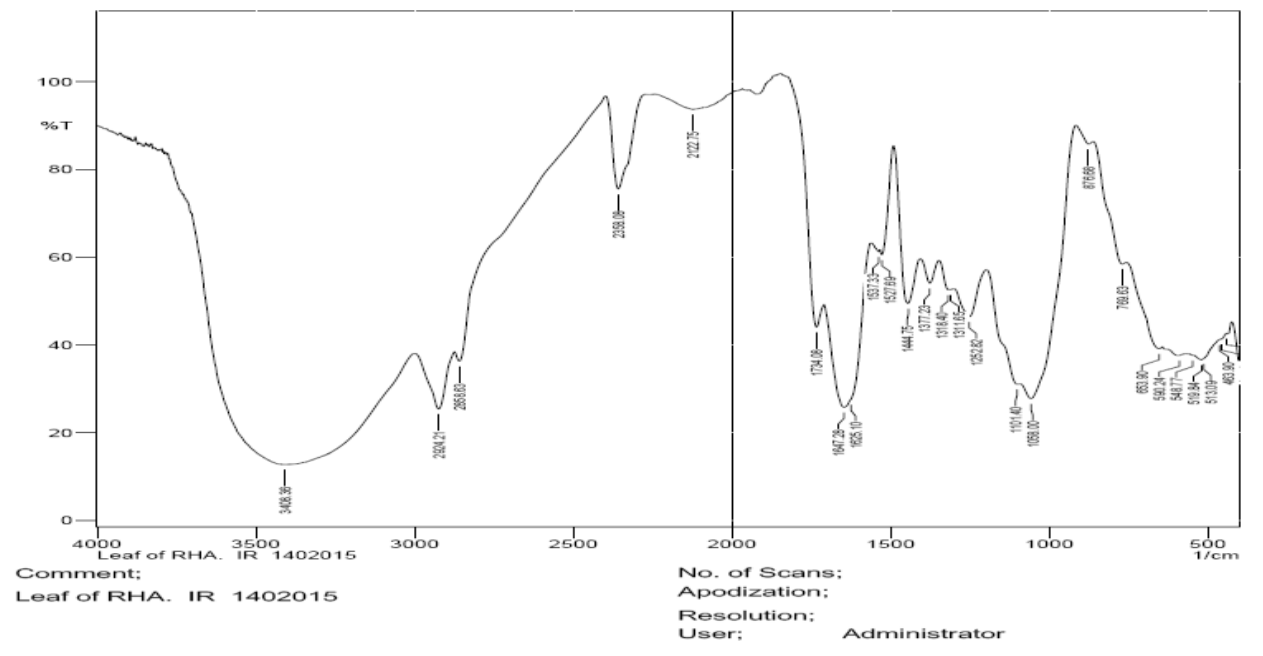


Fig.7 FTIR spectrum of B. cylindrica bark

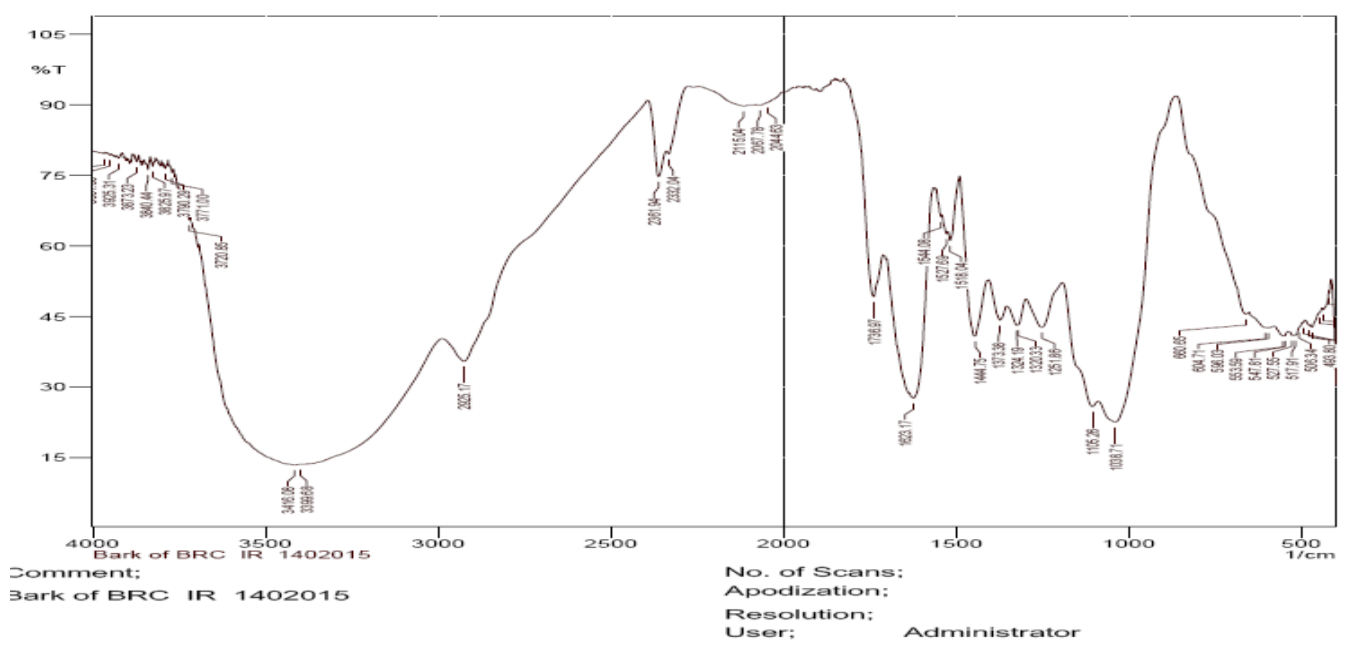

Fig.8 FTIR spectrum of $R$. apiculata bark

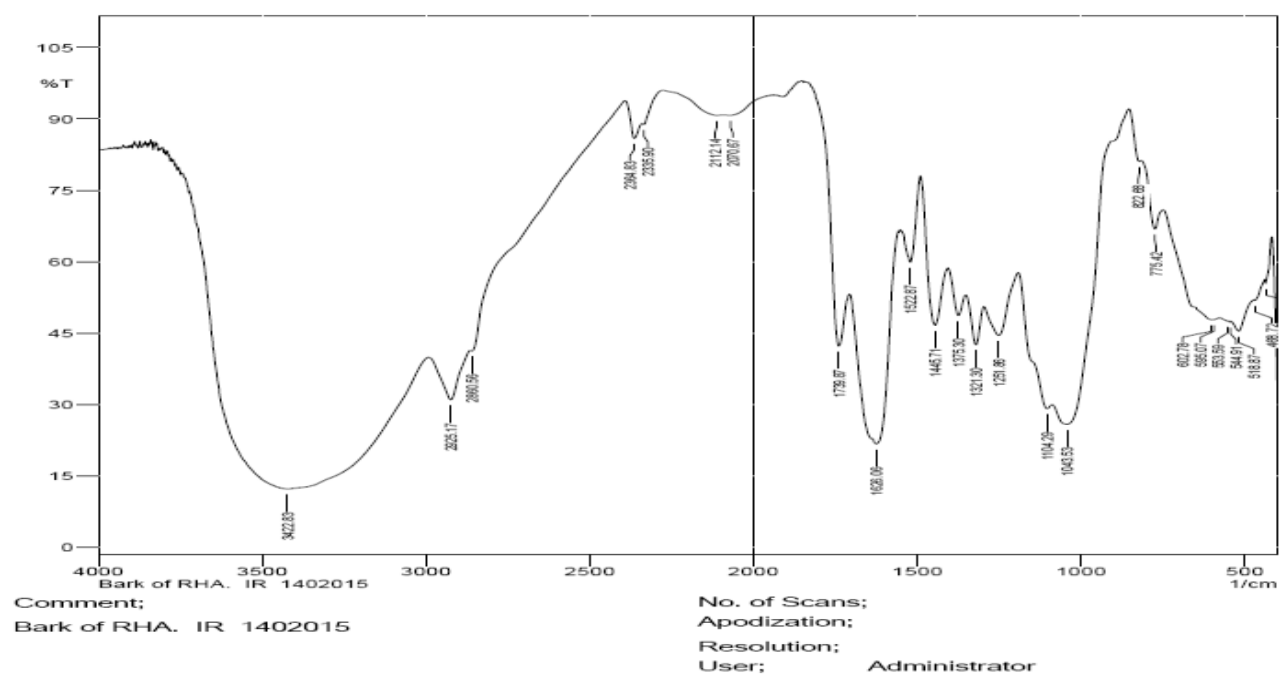

Fig.9 FTIR spectrum of B. cylindricl root

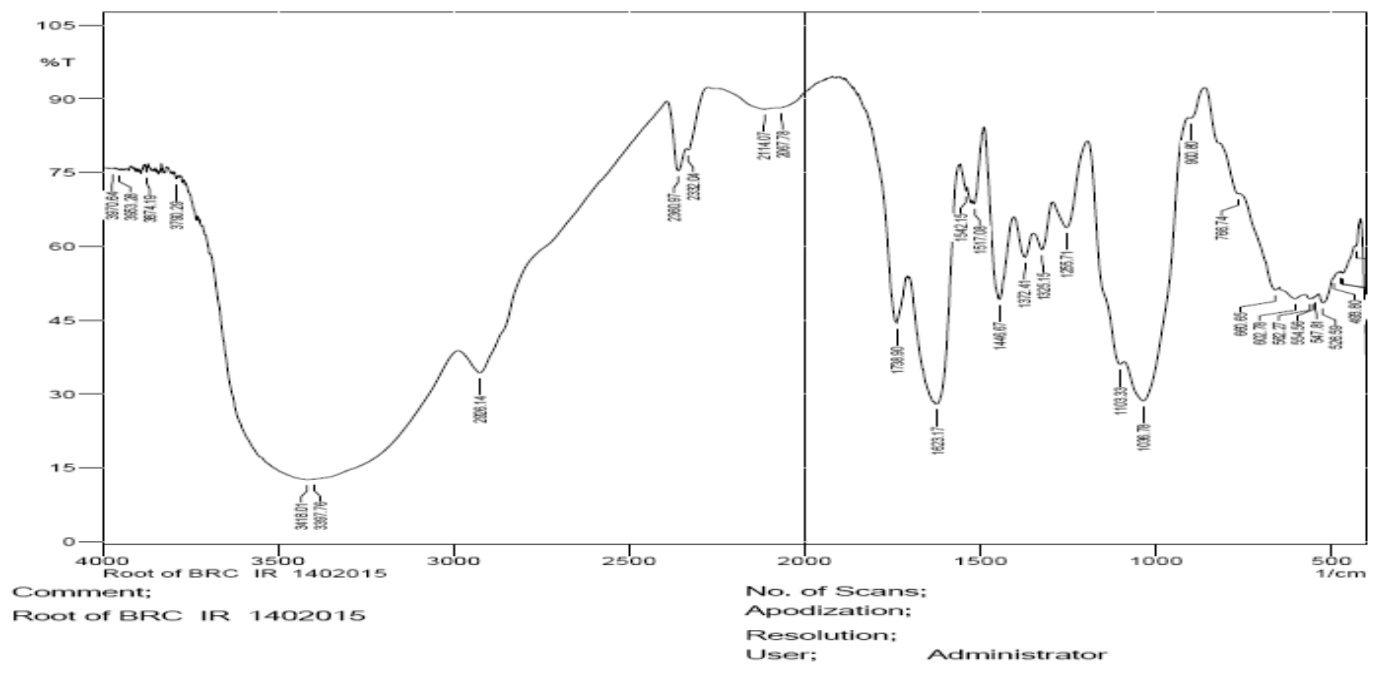


Fig.10 FTIR spectrum of $R$. apiculata root

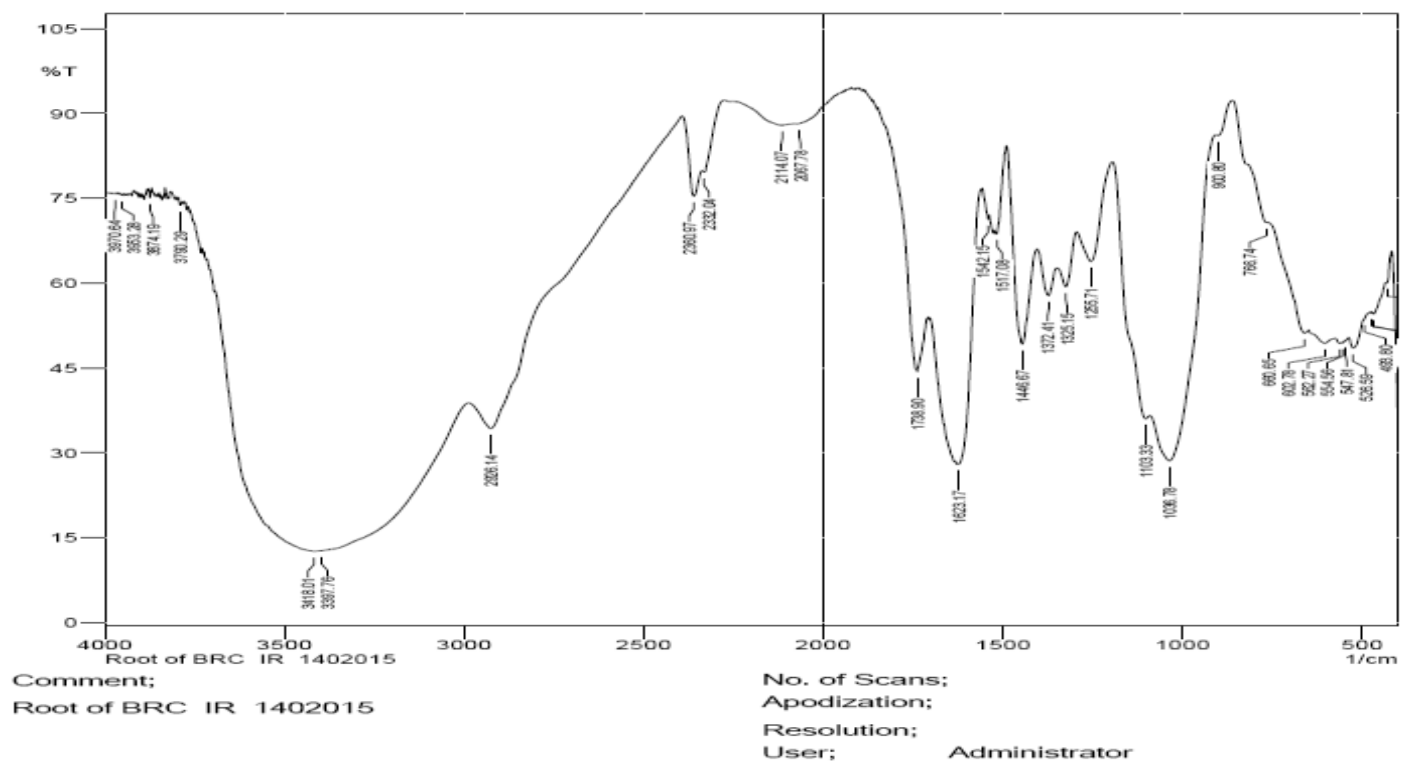

$\mathrm{AF}$ agents derived from natural products may be less environmentally harmful than the current toxic chemicals, having less activity against non-target species. The extracts of mangroves were reported to have AF properties (Chen et al., 2008). The present study also clearly showed that extracts from mangroves possess antimicrobial property against tested fouling bacteria. The effectiveness of the active compounds present in the plant extract showed growth inhibition as clear areas surrounding the well.

In vitro screening results showed that both the mangroves possess maximum antimicrobial activity against Vibrio parahaemolyticus $\quad \mathrm{BF}-1 \quad$ and Exiguobacterium profundum BF-5 and least against Vibrio nereis BF-2.These preliminary data suggest that extracts of Rhizophora apiculata and Bruguiera cylindrica may be used to develop an environmentally safe antifoulant to control fouling organisms. The inhibition activity is mainly correlated with the major functional groups like amino, hydroxyl, carbonyl and aliphatic group. The bonds such as $\mathrm{O}-\mathrm{H}$ stretch, H-bonded, $\mathrm{C}-\mathrm{H}$ stretch, $\mathrm{C}-\mathrm{O}$ stretch, $\mathrm{C}-\mathrm{Br}$ were present in all extracts and could be mainly involved in inhibition activity. Prabhakaran et al., have reported that mangroves showed higher activity against biofilm-forming bacteria compared to seaweed and seagrass extracts and should be further investigated with various fractions of the extracts.

The extracts of mangroves were reported to have AF properties (Chen et al., 2008). Similar studies done by Deepa et al., observed that Excoecaria agallocha and Kandelia candel showed promising AF results against fouling bacteria (V.vulnificus, V.parahaemolyticus, V.harveyi and V.alginolyticus), diatoms (N.subinflata and N.palea) and barnacle cyprid. Significant AF activity against P.vulgata was observed with methanol extract from A.marina, followed by extracts of B.cylindrica and A. Ilicifolius (Manilal 2009). Antioxidant activities of bark extract from mangroves, Bruguiera cylindrica (L) Blume and Ceriops decandra per indicates its potential as 
dietary supplements to treat chronic diseases caused by overproduction of free radicals (Krishnamoorthy et al., 2011). Ethanolic extract of Avicenna marina had different levels of antibacterial activity against antibiotic-resistant bacteria and eye pathogen (Ravikumar et al., 2011). Antisettlement against Balanus albicostantus was reported with Ceriops tagal because of diterpene methoxy-ent-814-pimarenely-15-one and it showed LC50 of $10 \mu / \mathrm{cm}^{2}$ (Chen et al., 2008).

In conclusion, the study of marine organisms for their bioactive potential has gained momentum in recent years and may provide valuable information for fouling control in the marine environment. This is the first and successful attempt on the studies of AF activity of mangroves against biofouling bacteria from boats. This study concludes by stating that bioactive compounds present in tested mangroves possess AF potential and will definitely aid in the development of natural antifoulants in the near future. Further studies are needed to identify the pure compounds, establish exact antibacterial mechanism and formulate it as effective antifoulants.

\section{Nucleotide sequence accession numbers}

All the five sequences were submitted to Genbank, the National Centre for Biotechnology Information (NCBI) through Bankit, and the accession numbers were given as: KR137715, KR137716, KR137717, KR137718 and KR137719.

\section{Acknowledgements}

The authors are thankful to the Principal, Faculty of Microbiology Department and Advanced Zoology and Biotechnology Department, Ethiraj College for Women, for providing the necessary facilities and support to carry out this research successfully.

\section{References}

Abeysinghe, P.D., Wanigatunge, R.P., Pathirana, R.N. 2006. Evaluation of antibacterial activity of different mangrove plant extracts. Ruhuna $J$. Sci., 1: 104-112.

Bandaranayake, W.M. 2002. Bioctivities, bioactive compounds and chemical constituents of mangrove plants. Wetland Ecol Manag., 10: 421-452.

Bhadury, P.,Wright, P.C. 2004. Exploitation of marine algae: biogenic compounds for potential antifouling applications. Planta, 219: 561-578.

Braithwaite, R.A., McEvoy, L.A. 2004. Marine biofouling on fish farms and its remediation. In: Southward AJ, Tyler PA, Young CM, Fuiman IA, editors. Advances in marine biology. New York: Academic Press; pp. 215252.

Briand, J. 2009. Marine antifouling laboratory bioassay: an overview of their diversity. Biofouling, 25(4): 297311.

Camps, M., Briand, J.F., GuentasDombrowsky, L., Culioli, G., Bazire, A., Blache, Y. 2011. Antifouling activity of commercial biocides vs. natural and natural-derived products assessed by marine bacteria adhesion bioassay. Mar. Pollut. Bull., 62: 1032-1040.

Chen, J.D., Feng, D.Q., Yang, Z.W., Wang, Z.C., Qin, Y., Lin, Y.M. 2008. Antifouling metabolites from the mangrove plant Ceriops tagal. Mol., 13: 212-219.

Deepa, S., Srikumar, M., Padmakumar, K. 2014. Antifouling potential of selected mangroves from Indian Coast. Int. J. Nat. Prod. Res., 4(2): 54-57. 
Krishnamoorthy, M., Sasikumar, J.M., Shamna, R., Pandia rajan, C., Sofia, P., Nagarajan, B. 2011. Indian J. Pharmacol., 43(5): 557-562.

Manilal, A., Sujith, S., Kiran, G.S., Selvin, J., Shakir, C. 2009. Biopotentials of mangroves from southwest Coast of India. Glob. J. Biotechnol. Biochem., 4(1): 59-65.

Manilal, A., Sujith, S., Sabarathnam, B., Kiran, G.S., Selvin, J., Shakir, C., Lipton, A.P. 2010. Antifouling potential of seaweeds collected from the southwest Coast of India. World J. Agric. Sci., 6(3): 243-248.

Nair, R., Chand, S.V. 2007. Antibacterial activities of some medicinal plants of the western region of India. Turk. J. Biol., 31: 231-236.

Nathan, P., Law, E.J., Murphy, D.F. 1978. A laboratory method for the selection of topical antimicrobial agents. Burns, 4: 177-178.

Patil, J.S., Kimoto, H., Kimoto, T., Saino, T. 2007. Ultraviolet radiation (UV-C); a potential tool for the control of biofouling on marine optical instrument. Biofouling, 23: 215-230.

Prabhakaran, S., Rajaram, R., Balasubramanian, V., Mathivanan, K.
2012. Antifouling potential of extracts from seaweeds, seagrasses and mangroves against primary biofilm forming bacteria. Asian Pac. J. Trop. Biomed., s316-s322.

Qian, P.Y., Xu, Y., Fusetani, N. 2010. Natural products as antifouling compounds: recent progress and future perspectives. Biofouling, 26: 223-234.

Raveendran, T.V., Limna, V.P.M. 2009. Natural product antifoulants. Curr. Sci., 97(4): 508-520.

Ravikumar, S., Ali, M.S., Ramu, A., Ferosekhan, M. 2011. Antibacterial activity of chosen mangrove plants against bacterial specified pathogens. World Appl. Sci. J., 14(8): 1198-1202.

Rios, J.L., Recio, M.C., Villar, A. 1988. Screening methods for natural products with antimicrobial activity: a reviewof the literature. $J$ Ethnopharmacol., 23: 127-149.

Yebra, D.M., Kiil, S., Johansen, K.D. 2004. Antifouling technology_past, present and future steps towards efficient and environmentally friendly antifouling coating. Prog in Org. Coating, 50: 75-104.

\section{How to cite this article:}

Nandhini, S., and Revathi, K. 2016. Antifouling Activity of Extracts from Mangroves against Biofouling Bacteria Isolated from Boats in Royapuram, Chennai, India. Int.J.Curr.Microbiol.App.Sci. 5(8): 324-335. doi: http://dx.doi.org/10.20546/ijcmas.2016.508.035 